\title{
Urban Gully Development in Southwestern Nigeria
}

\author{
Aderemi Adediji, Matthew Olomolatan Ibitoye \\ Department of Geography, Obafemi Awolowo University, Ile-Ife, Nigeria. \\ Email: remiadediji2003@yahoo.co.uk
}

Received December $11^{\text {th }}, 2012$; revised January $9^{\text {th }}, 2013$; accepted January $23^{\text {rd }}, 2013$

Copyright (C) 2013 Aderemi Adediji, Matthew Olomolatan Ibitoye. This is an open access article distributed under the Creative Commons Attribution License, which permits unrestricted use, distribution, and reproduction in any medium, provided the original work is properly cited.

\begin{abstract}
This study examined the development of urban gullies in a part of Southwestern Nigeria. This was done with a view to determine the volume and amount of sediment loss from the $1^{\text {st }}$ and $2^{\text {nd }}$ order gullies in a cascade system. Twenty (20) towns were randomly selected from where thirty (30) gully systems comprising forty (40) $1^{\text {st }}$ order and five (5) $2^{\text {nd }}$ order gullies were measured with Tape and Total Station (TS). The gully dimensions measured include gully lengths, depths and cross sectional areas. The core samples were also taken from the study gullies for the determination of the soil bulk density. The results showed that the mean volume of soil loss from the $1^{\text {st }}$ order and $\left(2^{\text {nd }}\right)$ order gullies in the study area are $1612.633 \mathrm{~m}^{3}$ and $1629.922 \mathrm{~m}^{3}$, respectively. The weight of the estimated sediment loss from the $1^{\text {st }}$ order and $2^{\text {nd }}$ order gullies are 2661.621 and 2657.318 tonnes, respectively. The result further showed that the total soil loss of 119661.442 tonnes was obtained from the study gullies and that the $1^{\text {st }}$ order gullies accounted for $87 \%$ (106,375 tonnes) of the total soil loss. This was an indication of soil degradation in the area.
\end{abstract}

Keywords: Urban Area; Gully Development; Accelerated Erosion; Southwestern Nigeria

\section{Introduction}

Gullies have been recognized as an important environmental threat in many parts of the world [1]. This phenomenon has been identified as a major factor in soil degradation, water quality deterioration and changes in channel morphology in the humid tropics [2]. Gullying could become even more severe in areas of high population growth especially in an urban centre and high rainfall intensity [3]. A number of gullies developed because of a decrease in the erosional resistance of the land surface or an increase in the erosional forces acting on land [4].

Soil erosion as related to anthropogenic factors in Nigeria is well documented in agriculture [5]. But, however, the fact that several Nigerian towns and cities are still experiencing erosion is not much known/documented. Though, urban gulling affects a relatively small part of the total land area of Nigeria, the land value of the portion of the land and infrastructure destroyed make it by far more harmful than in agricultural land [6]. Soil erosion in urban setting in Nigeria, has not been adequately studied or documented. For instance, [7-9] and [10], among others have focused mainly on erosion processes and the nature of the earth materials removed within some urban centres in Southern Nigeria, while $[11,12]$ examined off site effects of erosion on urban stream channels. Also, past studies, for example, [13,14] in AdoEkiti; [15] and $[16,17]$ in Ilorin, focused on the contribution of rainfall parameters on sediment generation and distribution from various land use surfaces in the urban areas. These studies showed that increase in volume of runoff generated from large areas of impermeable urban surfaces coupled with loose and incoherent nature of the soil on steep surfaces and from unpaired drains contributed largely to gully formation/development in urban areas [see 10]. Much as these studies contributed to the existing knowledge on urban gullying, however, they are based on very few gullies in very few urban centres. Urban gullying is becoming a topical issue worldwide and the outcry for prompt and proper management of this phenomenon call for in-depth knowledge and under- standing of gully initiation and development. Hence, this study attempts to assess the development of gullies from twenty towns/ cities in Ondo and Ekiti States of southwestern Nigeria. The main objective of this study is to document sediment loss from $1^{\text {st }}$ and $2^{\text {nd }}$ order gullies in urban areas of southwestern Nigeria.

\section{Study Area}

The two states of Ondo and Ekiti in southwestern Nigeria 
constitute the study area. The Ondo State is partially on sedimentary formations while Ekiti is mainly on Basement complex rocks. The choice of the two states was as a result of their true representation of southwest Nigeria (excluding Lagos State) in terms of geology and physiographical characteristics. The study area which is part of the eastern section of Southwest Nigeria lies between latitude $5^{\circ} 57^{\prime} \mathrm{N}$ and $9^{\circ} 12^{\prime} \mathrm{N}$ and longitude $2^{\circ} 40^{\prime} \mathrm{E}$ and $6^{\circ} 03^{\prime} \mathrm{E}$ (see Figure 1).

The population of the study area is $5,825,236$ (Ondo-
3,441,024 and Ekiti-2,384,212 (NPC, 2006). The people of the region are predominantly Yorubas comprising sub-groups such as Akures, Ekiti, Ondos, Ikales and Ilajes. Culturally, before the $19^{\text {th }}$ century, the Yorubas settled in agglomerations or clusters either in towns or villages. Prominent among these towns/cities are Akure, Owo, Ondo, Ikare, Okitipupa, Ado-Ekiti, Ikere, Ijero and Efon Alaaye among others. As observed by [7], the development of most of these towns and villages occurred without any systematic planning. Even today, the poor

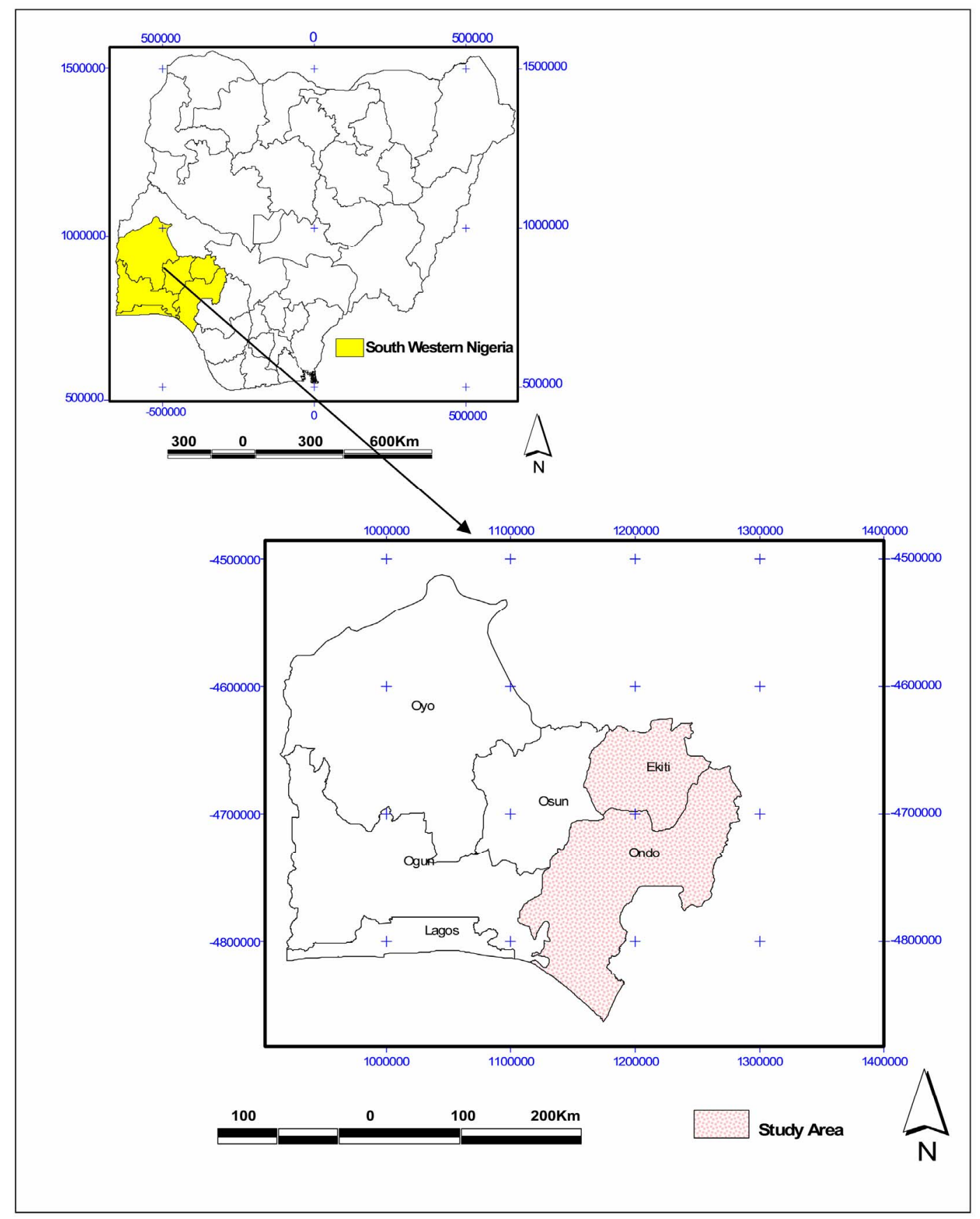

Figure 1. Map of Southwestern Nigeria showing the Study Area (Ondo and Ekiti States). 
execution of planning policy (especially residential layout design and implementation) often resulted in accelerated soil erosion in the study area and thus making the problem an urban phenomenon in this part of the humid tropics.

The study area is underlain especially at the southern part by Post-Jurassic sedimentary rocks and alluvium known as Coastal plain sands while the northern and central parts are mainly underlain by quartzite, quartzschist, magnetite, gneisses, granite gneisses, charnockites and coarse porphyritic-biotite granite rocks of the Precambrian Basement Complex [18]. Specifically, OkeImesi, Ijero, Efon-Alaaye, Ilawe axis of the study area was underlined by major rocks of the Ife-Ilesa Schist belt which comprises of Amphibolites complex schist's and Quartzite sequence [19]. These rocks constitute the parent materials of the Oke-Messi soil Association which comprised of different soil series. The most important are the gravelly, sandy and hill drift series [9]. On the whole, $70 \%$ of the studied gully systems fall within the various aspect of Basement Complex while 30\% are within Neocene in the Sedimentary formations.

The area is characterized by humid tropical climate (Am of Koppen's climatic classification) with mean annual temperature of $27^{\circ} \mathrm{C}$ and a mean annual rainfall ranging between $1250 \mathrm{~mm}$ and $1400 \mathrm{~mm}$ and distributed between the months of March and October with peaks in July and September, and short dry spell in August, though, this varying from year to year in its occurrence [20]. The rainfall effectiveness is between 6 - 9 months in the year [21]. The onset and withdrawal of the rains are marked by thunderstorms accompanied by high rainfall intensity [22].

Also, the forest and derived savanna communities of the study area are derivatives of the tropical rain and tropical deciduous forests which developed in a climatic region characterized by the dominance of humid over arid tropical conditions [23]. Gallery forests are also common along stream banks. However, this has also been severely altered as a result of encroachment from urban land use [24].

\section{Methods and Materials}

All settlements that fall within the demographic standard of the United Nation definition of urban towns of 20,000 and above inhabitants were compiled on state basis using 2006 population census figures on town basis. However, some towns that failed the above definition were included if they served as administrative headquarters or as university towns. The towns were further classified on the basis of those with gullies and without gullies. In all, 25 towns (13 in Ekiti and 12 in Ondo States) were identified to have serious gully occurrences. From the list, 20 towns were randomly selected using table of random numbers. This was done in order to have reasonable representation of the gullies in the study area. From each selected town, at least one gully site was selected for detail measurement of gully dimensions using line tape and Global, GPS Positioning system. In all, thirty (30) gully systems involving forty (40) $1^{\text {st }}$ order and five (5) $2^{\text {nd }}$ order gullies were selected and studied.

The processed data from the GPS and Total Station (TS) were stored in the Note pad of Microsoft office. The values of $\mathrm{X}$ and $\mathrm{Y}$ coordinates were later exported into Auto CAD environment from which gully widths, lengths and surface areas were determined using the geostatistical tool of the software. The average of the gully widths in the gully channel represents the gully width and was used in the determination of the cross sectional areas of the study gullies.

The cross sectional area for each point along the gully length was calculated using the equation described by $[25,26]$ and later expressed as

$$
A=w x d
$$

where, $A=$ Cross sectional area $\left(\mathrm{m}^{2}\right)$;

$w=$ width of the gully (m);

$d=$ depth (mean) depth of the gully (m).

The values of the cross sectional areas obtained were used to determine the volume of soil loss from the study gullies. Two methods available for the determination of volume of soil loss are End Area and Prismodal formula [see 27,28]. The End Area formula was used for the calculation of volume of soil loss because of its ability to calculate volume irrespective of whether the number of cross sectional areas is odd or even. The equation for the End Area is expressed as:

$$
\text { Volume }=1 / 2\left(y_{1}+y_{z}\right) d
$$

where, $d=$ the distance between cross sectional areas

$y_{1}=$ first sectional area;

$y_{2}=$ second sectional area.

Soil samples were taken from the gully shoulders (tops) and floors. The number of samples from each gully depends on the length and slope gradient [29]. Based on this principle, 60 samples were collected for textural properties analysis. In addition, core samples were also taken using McCauley sampler for the determination of soil bulk density which was used to estimate the weight of sediment loss (tonnes) from the study gullies. The soil particle size analysis was determined using hydrometer method [30]. The details on the methods adopted in this study are documented elsewhere [31].

\section{Results and Discussion}

\subsection{Soil Physical Characteristics}

The soil physical characteristics of the study gullies are 
shown in Table 1. As evident from the table, the values of bulk density obtained at the top soil, ranged between $1.29 \mathrm{~g} / \mathrm{cm}^{3}$ at Ijero and $1.82 \mathrm{~g} / \mathrm{cm}^{3}$ at Oke Ibedo, Ilawe with a mean of $1.53 \pm 0.112 \mathrm{~g} / \mathrm{cm}^{3}$ while the gully floor has values which ranged from $1.49 \mathrm{~g} / \mathrm{cm}^{3}$ at Odo Owa to $1.96 \mathrm{~g} / \mathrm{cm}^{3}$ at Usiri, Ikole and a mean of $1.72 \pm 0.135$ $\mathrm{g} / \mathrm{cm}^{3}$. As shown in the table, all the soils sampled irespective of depth exhibited high bulk density values which are far above $1.0-1.3 \mathrm{~g} / \mathrm{cm}^{3}$ considered for well aggregated forest or grassland vegetation $[32,33]$. Also, the values obtained in this study was in the same range for the values obtained for urbanized city of Miami-Dade and Gainesville in Florida which were averaged at 1.63 $\mathrm{g} / \mathrm{cm}^{3}$ and $1.52 \mathrm{~g} / \mathrm{cm}^{3}$, respectively [34,35]. The implication of high values of bulk density in the study area is that there would be reduction in the infiltration capacities of the soils, thus making the soil prone to greater runoff and soil loss. When this happens, more water would be generated as surface runoff in the case of a steep slope terrain and flooding as in the case of lowland area. When the run off flows downslope, there is tendency for it to create rills which may later converge down slope, especially if it is concentrated, to form gullies. The above process explains gully formation at Idogun and Orunbemiku in Ode Irele, Adu in Akure and Odo Ese $1^{\text {st }}$ order gullies II and III in Oke Imesi where the greater proportion of the surface runoff flows over heavily compacted urban roads from upslope of the study catchments.

Further, the soils in the study area are predominantly sandy clay with mean $\%$ sand $(53.43 \%)$, while clay and silt are $32.45 \%$ and $14.12 \%$, respectively at the gully top. At the gully floor, the clay content exhibits highest mean percent $(44.88 \%)$, followed by sand $(42.64 \%)$ and silt $(12.48 \%)$ Table 1 also showed that sand content decreases with soil depth while clay content increases with soil depth. Ordinarily, the high proportion of sand at the upper top soil could not have supported gully initiation but other factors such as high volume of run off as a result of increase in impermeable surfaces and other anthropogenic factors, most of the urban bare soils are easily susceptible to action of running water (runoff). The soils in this study exhibited higher clay content and higher bulk density at the gully floor. This further confirmed the finding [35] in their study of urban gullies in Sao Luis City, Brazil, where it was observed that soil with higher proportion of sand content associated with lower bulk density while soil with higher clay content have higher bulk density. At the gully top, the values of clay ratio ranged between 1.00 and 3.60 at Oke-Ibedo, Ilawe and Ajeka, Okitipupa, respectively with a mean value of 2.30 . The values at the gully floor was between 0.49 at Ikalako, Aramoko and 4.06 at Odo Osun, Igbara Oke with a mean value of 1.48 . The mean value of clay ratio (3.30) as an index of soil erobidibility further revealed the susceptibility of the top soil to gully initiation by running water in the study area.

\subsection{Gully Morphometry and Development}

Tables 2 and 3 showed the morphometric properties, volume of soil loss and total sediment loss from the study gullies. As evident from Table 2, the gully lengths ranged between $15 \mathrm{~m}$ at Ijemoji, Igede and $485.38 \mathrm{~m}$ at Ode Ose in Owo with the mean length of $131.44 \pm 90.70 \mathrm{~m}$. The gully depths ranged from about $0.6 \mathrm{~m}$ to $7.0 \mathrm{~m}$ with the shallowest depth at Odo pupa in Igede and the deepest at Ita Osun in Efon Alaaye. It has a mean value of $1.66 \pm$ $1.20 \mathrm{~m}$. Also, gully head depth varied from $0.13 \mathrm{~m}\left(1^{\text {st }}\right.$ order) at Odo Ese to $6.70 \mathrm{~m}$ at Ilutitun with the mean value of $1.76 \mathrm{~m} \pm 1.33 \mathrm{~m}$. Fifteen of the $1^{\text {st }}$ order gullies had head depths $\geq 2 \mathrm{~m}$, fourteen of which were formed as a result of abrupt termination half way of concrete channels. Gully widths ranged from $1.25 \mathrm{~m}$ at Idogun in Ode Irele to $17.09 \mathrm{~m}$ at Ode Ose in Owo with the mean value of $5.12 \pm 3.76 \mathrm{~m}$. based on the order, the mean depth values of $5.075 \pm 3.93 \mathrm{~m}$ and $5.506 \pm 2.284 \mathrm{~m}$ are obtained for the $1^{\text {st }}$ and $2^{\text {nd }}$ order, respectively (see Table 3). All these values of gullies dimensions suggest that gullies in the study area are moderate [36] when compared with observations by [25] in a part of southeastern Nigeria. Also, the deep gullies in the area exhibited unstable side wall as a result of sloughing and basal undermining. Sloughing is usually proceeded by side failure. Examples of gullies formed in this way are those at Okitipupa, Ilutitun and Ita Osun in Efon Alaaye.

The slope gradients of the study gully catchments ranged from $1^{\circ} 10^{\prime}$ to $8^{\circ} 25^{\prime}$, ordinarily under vegetal cover, these slope gradients would not enhance erosion processes but due to exposure to direct raindrop impact and human activities coupled with poor civil engineering work to control the runoff, gully has become pronounced virtually in all the catchments. For instance, building of drains along urban streets and concrete channels is a deliberate attempt to control surface runoff but the improper handling of such projects often accelerated or triggered gully formation and growth at the receiving location of the runoff. Specifically, many of the channels and drains constructed are at times abandoned or terminated half way before getting to the natural drainage channels (water bodies) (see Plates 1(a) and (b), Plates 2(a) and (b)). A total number of $24(60 \%) 1^{\text {st }}$ order gullies were identified to be triggered or accelerated in the study area due to abrupt termination of concrete channels half way. Gullies in this category include Ibaka in Akungba, Ikese in Oka-Akoko, Osinle in Akure, ItaOsun in Efon Alaaye etc.

Also, as evident from Table 3, a total of 119661.442 tonnes of sediment loss was obtained from all the gully 
Table 1. Soil Physical Properties of Gully Sites in the Study Area.

\begin{tabular}{|c|c|c|c|c|c|c|c|c|c|c|c|c|}
\hline \multirow{3}{*}{ Gully Locations } & \multirow{2}{*}{\multicolumn{2}{|c|}{$\begin{array}{c}\text { Bulk } \\
\text { Density }\end{array}$}} & \multicolumn{6}{|c|}{ Soil Texture } & \multirow{2}{*}{\multicolumn{2}{|c|}{ Clay Ratio }} & \multirow{2}{*}{\multicolumn{2}{|c|}{ Soil Class }} \\
\hline & & & \multicolumn{2}{|c|}{ Sand (\%) } & \multicolumn{2}{|c|}{ Clay (\%) } & \multicolumn{2}{|c|}{ Silt (\%) } & & & & \\
\hline & TOP & FLO & TOP & FLO & TOP & FLO & TOP & FLO & TOP & FLO & TOP & FLO \\
\hline Oke Ila, Ado Ekiti & 1.44 & 1.59 & 34.24 & 22.24 & 45.76 & 65.76 & 20.00 & 12.00 & 1.18 & 0.50 & $\mathrm{C}$ & $\mathrm{C}$ \\
\hline Ibaka, Akungba & 1.61 & - & - & - & - & - & - & - & - & - & - & - \\
\hline Adu, Akure & 1.72 & 1.68 & 52.80 & 50.24 & 33.20 & 37.76 & 14.00 & 12.00 & 2.01 & 1.65 & SCL & $\mathrm{SC}$ \\
\hline Osinle, Akure & 1.59 & 1.57 & 62.24 & 26.24 & 25.76 & 65.76 & 12.00 & 8.00 & 2.88 & 0.50 & $\mathrm{SCL}$ & $\mathrm{C}$ \\
\hline Ikalako, Aramoko & 1.49 & 1.69 & 46.24 & 20.80 & 37.76 & 67.20 & 16.00 & 12.00 & 1.65 & 0.49 & $\mathrm{SC}$ & $\mathrm{C}$ \\
\hline Oni Close, Aramoko & 1.59 & - & - & - & - & - & - & - & - & - & - & - \\
\hline Ita Osun, Efon Alaye & 1.69 & 1.80 & 66.24 & 28.24 & 25.76 & 49.76 & 8.00 & 22.00 & 2.89 & 1.01 & $\mathrm{SCL}$ & $\mathrm{C}$ \\
\hline Olofin Str., I/Odo & 1.62 & 1.63 & 32.80 & 32.24 & 47.20 & 51.76 & 20.00 & 16.00 & 1.12 & 0.93 & $\mathrm{C}$ & $\mathrm{C}$ \\
\hline St. Francis, I/Odo & 1.58 & 1.69 & 54.24 & 30.24 & 29.76 & 57.76 & 16.00 & 12.00 & 2.36 & 0.73 & $\mathrm{SCL}$ & $\mathrm{C}$ \\
\hline Odo Osun, I/Oke & 1.61 & 1.52 & 32.80 & 70.24 & 49.20 & 19.76 & 18.00 & 10.00 & 1.03 & 4.06 & $\mathrm{C}$ & SL \\
\hline Ijemoji, Igede & 1.47 & 1.95 & 58.24 & 42.24 & 29.76 & 45.76 & 12.00 & 12.00 & 2.36 & 1.18 & $\mathrm{SCL}$ & $\mathrm{C}$ \\
\hline Odopupa I\&II, Igede & 1.41 & 1.52 & 50.24 & 28.80 & 29.76 & 47.20 & 20.00 & 24.00 & 2.36 & 1.12 & $\mathrm{SCL}$ & $\mathrm{C}$ \\
\hline Agbangudu, Ijero & 1.29 & - & 62.24 & - & 25.76 & - & 12.00 & - & 2.88 & - & $\mathrm{SCL}$ & - \\
\hline AUD, Ikare & 1.38 & 1.65 & 42.24 & 46.24 & 33.76 & 37.76 & 20.00 & 16.00 & 1.96 & 1.65 & CL & $\mathrm{SC}$ \\
\hline Iyame I\&II, Ikare & 1.43 & 1.71 & 62.24 & - & 29.76 & - & 8.00 & - & 2.40 & - & $\mathrm{SCL}$ & - \\
\hline Usin, Ikole & 1.41 & 1.96 & 62.24 & 46.24 & 25.76 & 41.76 & 12.00 & 12.00 & 2.90 & 1.40 & $\mathrm{SCL}$ & $\mathrm{SC}$ \\
\hline Methodist, Ikole & 1.44 & 1.93 & 56.80 & 48.24 & 29.20 & 37.76 & 14.00 & 14.00 & 2.40 & 1.60 & $\mathrm{SCL}$ & $\mathrm{SC}$ \\
\hline Oke Bedo, Ilawe & 1.82 & - & 32.80 & - & 51.20 & - & 16.00 & - & 1.00 & - & $\mathrm{C}$ & - \\
\hline Eddy Hotel, Ilutitun & - & - & - & - & - & - & - & - & - & - & - & - \\
\hline Aduwo Str., Ode Aye & 1.59 & 1.70 & 70.24 & 30.24 & 21.76 & 55.76 & 8.00 & 14.00 & 3.60 & 0.79 & $\mathrm{SCL}$ & $\mathrm{C}$ \\
\hline Idogun, Ode Irele & 1.76 & 1.95 & 53.68 & 75.68 & 39.76 & 23.76 & 6.56 & 0.56 & 1.52 & 3.21 & $\mathrm{SC}$ & SCL \\
\hline Orunbemiku, Ode Irele & 1.54 & 1.82 & 71.68 & 53.68 & 21.76 & 43.76 & 6.56 & 2.56 & 3.60 & 1.29 & $\mathrm{SCL}$ & $\mathrm{SC}$ \\
\hline Awiri, Odo Owa & 1.54 & 1.49 & 38.24 & 44.80 & 45.76 & 39.20 & 16.00 & 16.00 & 1.79 & 1.55 & $\mathrm{C}$ & CL \\
\hline Ikese, Oka & 1.38 & 1.84 & 50.24 & 54.24 & 29.76 & 37.76 & 20.00 & 8.00 & 2.40 & 1.60 & $\mathrm{SCL}$ & $\mathrm{SC}$ \\
\hline Odo Ese, Oke Imesi & 1.51 & 1.78 & 44.24 & 50.24 & 35.76 & 29.76 & 20.00 & 20.00 & 1.80 & 2.36 & $\mathrm{CL}$ & SCL \\
\hline Odo Iro, Oke Imesi & 1.56 & 1.71 & 58.24 & 24.80 & 29.76 & 59.20 & 12.00 & 16.00 & 2.36 & 0.69 & $\mathrm{SCL}$ & $\mathrm{C}$ \\
\hline Ayeka, Okitipupa & 1.62 & 1.71 & 62.24 & 46.24 & 21.76 & 49.76 & 16.00 & 4.00 & 3.60 & 1.01 & $\mathrm{SCL}$ & $\mathrm{SC}$ \\
\hline Apata, Okitipupa & 1.49 & - & 62.24 & - & 25.76 & - & 12.00 & - & 2.9 & - & $\mathrm{SCL}$ & - \\
\hline Idimepen, Owo & 1.34 & 1.70 & 60.80 & 38.24 & 27.20 & 45.76 & 12.00 & 16.00 & 2.68 & 1.18 & $\mathrm{SCL}$ & $\mathrm{C}$ \\
\hline Odo Ose, Owo & 1.47 & 1.64 & 62.24 & 70.27 & 27.76 & 21.76 & 10.00 & 8.00 & 2.60 & 3.60 & $\mathrm{SCL}$ & SCL \\
\hline$\Sigma$ & 44.39 & 41.23 & 142.72 & 980.67 & 878.16 & 1032.24 & 377.12 & 287.12 & 62.23 & 34.10 & & \\
\hline$\dot{\mathbf{X}}$ & 1.53 & 1.72 & 53.43 & 42.64 & 32.45 & 44.88 & 14.12 & 12.48 & 2.30 & 1.48 & & \\
\hline
\end{tabular}

Source: Fieldwork, 2011; C = Clay; $\mathrm{SC}=$ Sandy clay; $\mathrm{SL}=$ Sandy loam, $\mathrm{SCL}=$ Sandy clay loam; TOP = Soil properties at gully top; FLO = Soil properties at gully floor. 
Table 2. Morphometric Attributes of the Studied Gullies.

\begin{tabular}{|c|c|c|c|c|c|c|c|c|c|}
\hline Gully location & Order & Width (m) & Depth (m) & Length (m) & Slope Gradient & $\begin{array}{c}\text { Surface } \\
\text { Area }\left(\mathbf{m}^{2}\right)\end{array}$ & $\operatorname{CSA}\left(\mathbf{m}^{2}\right)$ & $\begin{array}{c}\text { Depth of gully } \\
\text { Head }\end{array}$ & $\begin{array}{c}\text { Width/ } \\
\text { Depth } \\
\text { ratio }\end{array}$ \\
\hline Oke Ila, Ado Ekiti & 1 & 3.42 & 1.76 & 237.47 & $3^{\circ} 59^{\prime} 18^{\prime \prime}$ & 752.273 & 7.56 & 2.36 & 6.02 \\
\hline Ibaka, Akungba I & 1 & 7.58 & 1.70 & 85.42 & $2^{\circ} 21^{\prime} 41^{\prime \prime}$ & 872.176 & 3.89 & 2.12 & 4.46 \\
\hline Ibaka, Akungba II & 1 & 3.77 & 0.83 & 41.16 & $4^{\circ} 08^{\prime} 45^{\prime \prime}$ & 132.777 & 13.39 & 0.85 & 4.45 \\
\hline Ibaka, Akungba & 2 & 7.09 & 0.91 & 355.33 & $0^{\circ} 51^{\prime} 49^{\prime \prime}$ & 2485.241 & 7.15 & $*$ & 7.79 \\
\hline Adu, Akure & 1 & 2.48 & 0.93 & 119.20 & $2^{\circ} 35^{\prime} 33^{\prime \prime}$ & 281.649 & 2.64 & 2.05 & 2.67 \\
\hline Osinle, Akure I & 1 & 2.85 & 1.18 & 123.13 & $3^{\circ} 41^{\prime} 14^{\prime \prime}$ & 338.698 & 3.45 & 1.28 & 2.42 \\
\hline Osinle, Akure II & 1 & 1.58 & 0.78 & 44.61 & $3^{\circ} 41^{\prime} 14^{\prime \prime}$ & 80.540 & 1.36 & 1.57 & 2.03 \\
\hline Ikalako, Aramoko & 1 & 2.54 & 1.46 & 177.94 & $1^{\circ} 43^{\prime} 06^{\prime \prime}$ & 454.175 & 3.66 & 1.30 & 1.74 \\
\hline Oni Close, Aramoko & 1 & 2.06 & 0.68 & 72.97 & $3^{\circ} 25^{\prime} 04^{\prime \prime}$ & 155.703 & 1.50 & 0.83 & 3.03 \\
\hline Ita Osun, Efon Alaye & 1 & 13.35 & 6.91 & 98.78 & $6^{\circ} 21^{\prime} 05^{\prime \prime}$ & 1235.888 & 58.01 & 5.00 & 1.93 \\
\hline Olofin Str., I/Odo & 1 & 2.38 & 0.99 & 115.75 & $2^{\circ} 51^{\prime} 45^{\prime \prime}$ & 256.295 & 2.38 & 1.06 & 2.40 \\
\hline St. Francis, I/Odo & 1 & 2.96 & 1.20 & 227.11 & $1^{\circ} 37^{\prime} 23^{\prime \prime}$ & 606.234 & 3.74 & 0.20 & 2.46 \\
\hline Odo Osun, I/Oke & 1 & 5.13 & 1.16 & 144.19 & $1^{\circ} 53^{\prime} 36^{\prime \prime}$ & 618.655 & 6.75 & 1.52 & 4.42 \\
\hline Ijemoji, Igede I & 1 & 2.07 & 0.63 & 19.14 & $2^{\circ} 41^{\prime} 16^{\prime \prime}$ & 41.301 & 1.41 & 0.35 & 3.29 \\
\hline Ijemoji, Igede II & 1 & 3.45 & 1.06 & 14.59 & $2^{\circ} 41^{\prime} 16^{\prime \prime}$ & 41.834 & 2.21 & 0.88 & 3.25 \\
\hline Ijemoji, Igede & 2 & 3.41 & 0.80 & 151.53 & $2^{\circ} 41^{\prime} 16^{\prime \prime}$ & 437.721 & 2.56 & $*$ & 4.26 \\
\hline Odopupa, Igede I & 1 & 3.56 & 1.50 & 132.81 & $2^{\circ} 00^{\prime} 16^{\prime \prime}$ & 392.063 & 3.50 & 2.10 & 2.37 \\
\hline Odopupa, Igede II & 1 & 3.32 & 0.58 & 85.50 & $2^{\circ} 00^{\prime} 16^{\prime \prime}$ & 264.936 & 1.76 & 0.38 & 5.72 \\
\hline Agbangudu, Ijero & 1 & 4.33 & 1.19 & 83.80 & $7^{\circ} 10^{\prime} 19^{\prime \prime}$ & 337.696 & 6.04 & 2.17 & 3.64 \\
\hline AUD, Ikare & 1 & 7.22 & 1.17 & 271.67 & $1^{\circ} 00^{\prime} 09^{\prime \prime}$ & 2866.867 & 6.45 & 2.4 & 6.15 \\
\hline Iyame Ikare I & 1 & 9.93 & 2.09 & 171.69 & $3^{\circ} 41^{\prime} 14^{\prime \prime}$ & 2532.472 & 22.15 & 1.67 & 4.75 \\
\hline Iyame, Ikare II & 1 & 9.24 & 1.48 & 202.90 & $1^{\circ} 21^{\prime} 58^{\prime \prime}$ & 2064.930 & 12.00 & 1.24 & 6.24 \\
\hline Usin, Ikole & 1 & 4.51 & 1.26 & 133.34 & $3^{\circ} 24^{\prime} 07^{\prime \prime}$ & 547.186 & 5.54 & 0.80 & 3.58 \\
\hline Methodist, Ikole & 1 & 2.66 & 1.36 & 200.18 & $2^{\circ} 55^{\prime} 33^{\prime \prime}$ & 482.228 & 3.95 & 1.79 & 1.96 \\
\hline Oke Bedo, Ilawe & 1 & 15.48 & 2.92 & 114.64 & $2^{\circ} 24^{\prime} 07^{\prime \prime}$ & 1942.671 & 47.40 & 4.04 & 5.30 \\
\hline Eddy Hotel, Ilutitun & 1 & 11.78 & 3.10 & 178.63 & $2^{\circ} 26^{\prime} 58^{\prime \prime}$ & 1882.278 & 59.91 & 6.70 & 3.80 \\
\hline Aduwo Str., Ode Aye & 1 & 4.31 & 3.40 & 236.77 & $2^{\circ} 13 ' 37^{\prime \prime}$ & 971.936 & 9.76 & 1.87 & 1.27 \\
\hline Idogun, Ode Irele & 1 & 1.25 & 0.82 & 94.94 & $4^{\circ} 40^{\prime} 08^{\prime \prime}$ & 119.011 & 1.05 & 0.40 & 1.52 \\
\hline Orunbemiku, Ode Irele & 1 & 1.94 & 1.20 & 136.85 & $2^{\circ} 15^{\prime} 32^{\prime \prime}$ & 252.394 & 2.33 & 1.03 & 1.62 \\
\hline Awiri, Odo Owa & 1 & 2.27 & 2.78 & 84.59 & $3^{\circ} 12^{\prime} 42^{\prime \prime}$ & 640.623 & 25.54 & 2.33 & 0.82 \\
\hline Ikese, Oka I & 1 & 6.25 & 1.56 & 131.29 & $2^{\circ} 32^{\prime} 41^{\prime \prime}$ & 739.133 & 10.59 & 3.00 & 4.01 \\
\hline Ikese, Oka II & 1 & 3.88 & 1.05 & 80.79 & $1^{\circ} 17^{\prime} 20^{\prime \prime}$ & 328.501 & 4.25 & 1.05 & 3.69 \\
\hline Ikese, Oka & 2 & 6.72 & 1.65 & 75.12 & $1^{\circ} 16 ' 23^{\prime \prime}$ & 507.995 & 10.19 & $*$ & 4.07 \\
\hline Odo Ese, Oke Imesi I & 1 & 6.01 & 2.25 & 171.12 & $2^{\circ} 50^{\prime} 48^{\prime \prime}$ & 1017.815 & 13.74 & 1.20 & 2.67 \\
\hline Odo Ese, Oke Imesi II & 1 & 2.07 & 0.75 & 114.40 & $4^{\circ} 59^{\prime} 05^{\prime \prime}$ & 261.795 & 1.46 & 0.13 & 2.76 \\
\hline Odo Ese, Oke Imesi III & 1 & 2.29 & 0.90 & 90.90 & $5^{\circ} 04^{\prime} 47^{\prime \prime}$ & 176.809 & 2.83 & 0.51 & 2.54 \\
\hline Odo Iro, Oke Imesi I & 1 & 2.26 & 1.30 & 31.42 & $2^{\circ} 48^{\prime} 53^{\prime \prime}$ & 58.742 & 3.41 & 1.94 & 1.74 \\
\hline Odo Iro, Oke Imesi II & 1 & 1.48 & 0.74 & 18.60 & $3^{\circ} 01^{\prime} 16^{\prime \prime}$ & 23.230 & 1.23 & 0.30 & 2.00 \\
\hline
\end{tabular}


Continued

\begin{tabular}{cccccccccc}
\hline Odo Iro, Oke Imesi & 2 & 2.68 & 1.85 & 86.720 & $2^{\circ} 46^{\prime} 59^{\prime \prime}$ & 217.659 & 4.51 & $*$ & 1.45 \\
Ayeka, Okitipupa & 1 & 7.67 & 5.22 & 48.49 & $4^{\circ} 48^{\prime} 40^{\prime \prime}$ & 441.200 & 32.04 & 2.96 & 1.47 \\
Apata, Okitipupa & 1 & 3.62 & 1.89 & 220.91 & $2^{\circ} 10^{\prime} 46^{\prime \prime}$ & 797.174 & 9.03 & 2.00 & 1.92 \\
Idimepen, Owo & 1 & 3.57 & 1.07 & 56.57 & $0^{\circ} 56^{\prime} 20^{\prime \prime}$ & 201.950 & 4.24 & 1.13 & 3.34 \\
Odo Ose, Owo I & 1 & 9.40 & 2.07 & 57.33 & $4^{\circ} 29^{\prime} 41^{\prime \prime}$ & 524.920 & 23.25 & 2.36 & 4.54 \\
Odo Ose, Owo II & 1 & 17.09 & 2.86 & 88.97 & $2^{\circ} 38^{\prime} 24^{\prime \prime}$ & 1331.660 & 49.36 & 3.39 & 6.00 \\
Odo Ose, Owo & 2 & 7.63 & 1.90 & 485.38 & $1^{\circ} 43^{\prime} 06^{\prime \prime}$ & 3544.606 & 11.14 & $*$ & 4.02 \\
Mean & & $\mathbf{5 . 1 2}$ & $\mathbf{1 . 6 6}$ & $\mathbf{1 3 1 . 4 3 6}$ & & $\mathbf{7 6 1 . 3 7 0}$ & $\mathbf{1 1 . 3 4 0}$ & $\mathbf{1 . 7 6}$ & $\mathbf{3 . 3 7}$ \\
\hline
\end{tabular}

Source: Fieldwork, 2011; The gullies are $2^{\text {nd }}$ order and they have no gully heads.

Table 3. Descriptive Analysis of Some Gully Morphometric Attributes Based on Gully Order.

\begin{tabular}{|c|c|c|c|c|c|c|c|c|c|c|}
\hline Order & & Width (m) & Depth (m) & Length (m) & $\begin{array}{c}\text { Surface } \\
\text { Area }\left(\mathbf{m}^{2}\right) \\
\end{array}$ & $\begin{array}{c}\text { Depth of Gully } \\
\text { Head (m) }\end{array}$ & $\begin{array}{c}\text { Width/Depth } \\
\text { ratio }\end{array}$ & $\begin{array}{c}\text { CSA } \\
\text { (sq.m) }\end{array}$ & $\begin{array}{l}\text { Vol of Soil } \\
\text { Loss }\left(\mathbf{m}^{3}\right) \\
\end{array}$ & $\begin{array}{c}\text { Sediment Loss } \\
\text { (tonnes) }\end{array}$ \\
\hline \multirow[t]{5}{*}{1} & Mean & 5.075 & 1.695 & 119.014 & 676.711 & 1.756 & 3.250 & 11.869 & 1612.633 & 2661.621 \\
\hline & Std. deviation & 3.926 & 1.259 & 66.953 & 698.614 & 1.328 & 1.503 & 15.932 & 2344.50 & 3924.398 \\
\hline & Minimum & 1.25 & 0.58 & 14.59 & 23.23 & 0.13 & 0.82 & 1.05 & 21.95 & 35.91 \\
\hline & Maximum & 17.09 & 6.91 & 271.67 & 2866.87 & 6.7 & 6.24 & 59.91 & 10810.23 & 17545.0 \\
\hline & Std. error of mean & 0.621 & 0.199 & 10.586 & 110.461 & 0.210 & 0.238 & 2.519 & 370.698 & 620.502 \\
\hline \multirow[t]{5}{*}{2} & Mean & 5.506 & 1.422 & 230.816 & 1438.644 & & 4.318 & 7.11 & 1629.922 & 2657.318 \\
\hline & Std. deviation & 2.285 & 0.527 & 181.382 & 1490.738 & & 2.260 & 3.647 & 1646.508 & 2685.148 \\
\hline & Minimum & 2.68 & 0.8 & 75.12 & 217.66 & & 1.45 & 2.56 & 391.18 & 672.83 \\
\hline & Maximum & 7.63 & 1.9 & 485.38 & 3544.61 & & 7.79 & 11.14 & 4334.88 & 7087.59 \\
\hline & Std. error of mean & 1.022 & 0.236 & 81.116 & 666.678 & & 1.011 & 1.631 & 736.341 & 1200.835 \\
\hline \multirow[t]{5}{*}{ Total } & Mean & 5.123 & 1.664 & 131.436 & 761.370 & 1.756 & 3.368 & 11.340 & 1614.554 & 2661.143 \\
\hline & Std. deviation & 3.763 & 1.199 & 90.702 & 832.627 & 1.328 & 1.607 & 15.116 & 2262.42 & 3782.361 \\
\hline & Minimum & 1.25 & 0.58 & 14.59 & 23.23 & 0.13 & 0.82 & 1.05 & 21.95 & 35.91 \\
\hline & Maximum & 17.09 & 6.91 & 485.38 & 3544.61 & 6.70 & 7.79 & 59.91 & 10810.23 & 17545.0 \\
\hline & Std. error of mean & 0.561 & 0.179 & 13.521 & 124.121 & 0.210 & 0.240 & 2.253 & 337.262 & 563.841 \\
\hline
\end{tabular}

Source: Field Work, 2011.

systems in the entire study area. This value was in the same range with the sediment loss of 116,402 tonnes obtained from a single urban gully system at Queen Ede College Road, Benin City in 1992 (see [9]). Out of this total sediment loss, 106,375 tonnes $(89 \%)$ was estimated from the $1^{\text {st }}$ order study gullies. However, it is of interest to note that sediment loss from Efon Alaaye gullies (10697.80 tonnes) was drastically reduced when compared with 31,150 tonnes obtained for the same gullies in 1995 [9]. This decline was as a result of aggressive engineering erosion control measures adopted by the government.

\section{Conclusions}

This study investigated the development of urban gullies in southwestern Nigeria. Gullies from twenty towns randomly selected from both Ondo and Ekiti States were measured for determination of their dimensions (lengths, widths, depths and surface areas) as well as volume of soil loss and weight of sediment loss.

It was established that gullies in the area were of $1^{\text {st }}$ and $2^{\text {nd }}$ order, with $1^{\text {st }}$ order dominating $(85 \%)$ the gully systems. The gully dimensions measured revealed a mean width ranged from $1.25 \mathrm{~m}$ at Idogun to $17.09 \mathrm{~m}$ at Ose in Owo with overall mean depth of $5.12 \pm 3.76 \mathrm{~m}$. The 


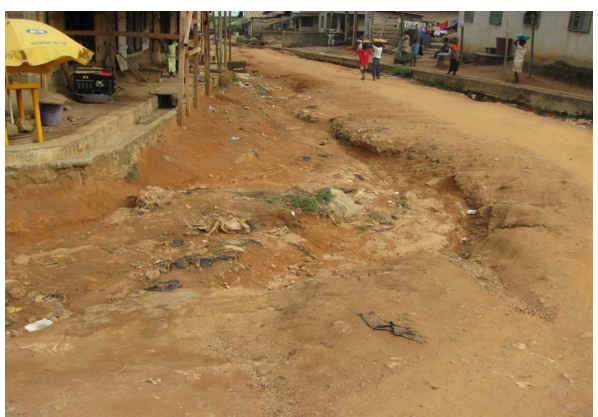

(a)

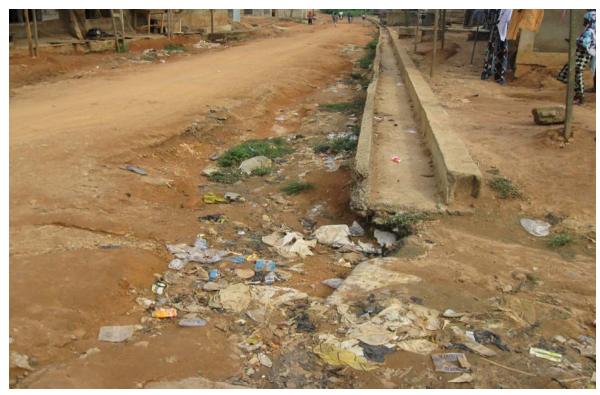

(b)

Plate 1. (a) \& (b) Typical drains constructed to conduct surface runoff at a street in Ore.

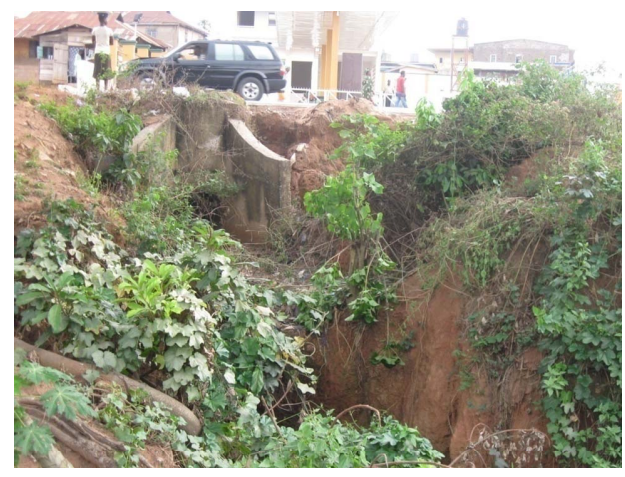

(a)

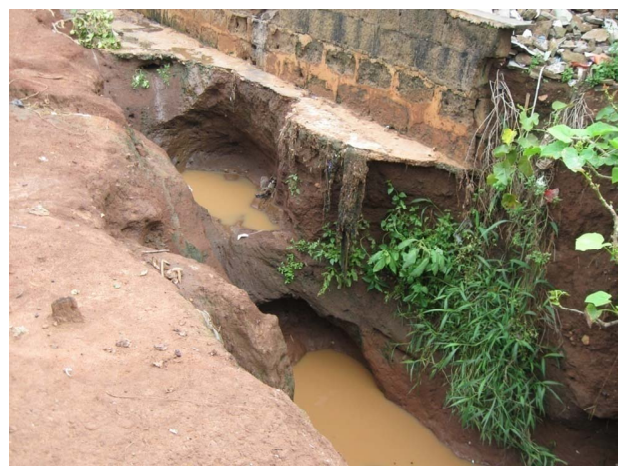

(b)

Plate 2. (a) A Gully Caused by the Half Way Termination of a Concrete Channel at Ose Gully in Owo; (b) A Gully Caused by the Half Way Termination of a Concrete Channel at the Back of the Gospel Faith Mission Church, Oke Ila, Ado Ekiti. mean depth ranged approximately from $0.6 \mathrm{~m}$ to $7.0 \mathrm{~m}$ with shallowest gullies at Odo pupa, Igede and deepest at Ita Osun, Efon Alaaye with $1.66 \pm 1.20 \mathrm{~m}$. The gully head depth varies from $0.13 \mathrm{~m}$ at Odo Ese, Oke Imesi to $6.7 \mathrm{~m}$ at Eddy Hotel, Ilu titun with a mean value of 1.756 \pm 1.33 . It must be noted that the deep gullies exhibited unstable sidewall as a result of sloughing involving basal undermining and slumping. Also, the mean cross sectional area (CSA) ranged between $1.05 \mathrm{~m}^{2}$ at a $1^{\text {st }}$ order gully, Idogun in Irele and $59 \mathrm{~m}^{2}$ at Eddy Hotel in Ilutitun. The highest soil loss of 24,232 tonnes was obtained at Ose in owo. The second and third highest values of 17,545 and 11,546.142 tonnes were obtained from Eddy Hotel, Ilutitun and Oke-Ibedo, Ilawe, respectively. Most of the $1^{\text {st }}$ order gullies development or formation may not be unconnected to uncontrolled street surface runoff. It was also revealed that 14 out of 15 gullies with the gully head depth $\geq 2 \mathrm{~m}$ were formed as a result of uncontrolled surface runoff.

On the whole, gully initiation and development in the study area (Ondo and Ekiti States) have contributed immensely to environmental degradation in many of the towns studied. Also, the values of gully dimensions (widths, depths and lengths) indicated that the development has not reached a disaster level, but the restoration of damage done require assistance from the outside especially from the government and Non-Government Organizations (NGOs).

\section{REFERENCES}

[1] I. Ionita, "Gully Development in Moldarian Plateaus of Romania," Journal of Environmental Management, Vol. 68, No. 2-3, 2006, pp. 133-140.

[2] A. M. J. Meijerink, H. A. M. Brouwer, C. M. Mannaerts and C. Velenzuela, "Introduction to the Use of Geographical Information Systems for Practical Hydrology," ITC, Vol. 23, No. 2, 1994, p. 243.

[3] M. Marker and A. Sidorchuk, "Assessment of Gully Erosion Process Dynamics for Water Resources Management in a Semi Arid Catchment of Swaziland (South Africa). Erosion Production in Unganged Basins," IANS, Vol. 279, No. 1, 2003, pp. 188-198.

[4] E. A. Bettis III, "Gully Erosion," Iowa Department Survey No. 8, Iowa Department of Natural Resources, Iowa, 1983.

[5] H. K. Watson and R. Ramokgopa, "Factors Influencing the Distribution of Gully Erosion in Kwazulu Natal's Mfolozi Catchment-Land Reform Implication in South Africa," Journal of Land Degradation and Development, Vol. 10. No. 1, 1997, pp. 223-230.

[6] R. Ledger, "Urban Gully Erosion in USSR, JSTOR," CATENA, Vol. 8, No. 1, 1968, pp. 22-29.

[7] L. K. Jeje, "Soil Erosion Characteristics, Processing and Extent in the Lowland Rainforest Area of Southwestern Nigeria," In: V. O. Sagua, E. E. Enabor, G. E. K. Ofo- 
mata, K. O. Ologe and O. Lekan, Eds., Ecological Disaster in Nigeria: Soil Erosion, Federal Ministry of Science and Technology, Lagos, 1988, pp. 69-83.

[8] L. K. Jeje, "Urbanization and Accelerated Erosion: The Case of Efon Alaaye, Ondo State, Nigeria," Paper Presented at Scope-IUGS Workshop on Earth Surface Processes, Material Use and Urban Development, Understanding the Human Contribution to Global Geomorphological Change, Spain, March 1995.

[9] L. K. Jeje, "Urbanization and Accelerated Erosion: Examples from Southwestern Nigeria," Environmental Management Journal, Vol. 2, No. 1, 2005, pp. 1-17.

[10] T. O. Okoye, "Urbanization, and Erosion with Particular Reference to Aba,” In: V. O. Sagua, E. E. Enabor, G. E. K. Ofomata, K. O. Ologe and O. Lekan, Eds., Ecological Disaster in Nigeria: Soil Erosion, Federal Ministry of Science and Technology, Lagos, 1988, pp. 265-275.

[11] L. K. Jeje and S. I. Ikeazota, "Effects of Urbanization on Channel Morphology: The Case of Ekulu River in Enugu, Southeastern Nigeria," Singapore Journal of Tropical Geography, Vol. 23, No. 1, 2002, pp. 37-51.

[12] A. Adediji and L. K. Jeje, "Channel Erosion in the Opa Basin, Southwestern Nigeria," Journal of Environmental Hydrology, Vol. 12, No. 10, 2004, pp. 1-11.

[13] S. F. Ebisemiju, "The Response of Headwater Channels to Urbanization in the Humid Tropics," Hydrological Processes, Vol. 3, No. 3, 1989, pp. 237-253. doi:10.1002/hyp.3360030304

[14] S. F. Ebisemiju, "Patterns of Stream Channel Response to Urbanization in the Humid Tropics and Their Implications for Urban Land Use Planning: A Case Study of Southwestern Nigeria," Applied Geography, Vol. 9, No. 4, 1989, pp. 273-286. doi:10.1016/0143-6228(89)90028-3

[15] R. O. Oyegun, "Sediment Redistribution in Ilorin, Nigeria," The Environmentalist, Vol. 7, No. 2, 1987, pp. 259268. doi:10.1007/BF02240295

[16] H. I. Jimoh, "Tropical Rainfall Events on Erosion Rates in a Rapidly Developing Urban Area in Nigeria," Singapore Journal of Tropical Geography, Vol. 26, No. 1, 2005, pp. 74-81. doi:10.1111/i.0129-7619.2005.00205.x

[17] H. I. Jimoh, "Individual Rainfall and Sediment Generation in Different Surfaces in Ilorin, Nigeria," Unpublished Ph.D. Thesis, University of Ilorin, Ilorin, 1997.

[18] A. Y. B. Anifowose, "The Performance of Some Soils under Stabilization in Ondo State Nigeria," Engineering Geology, Vol. 40, No. 1, 1989, pp. 79-83.

[19] A. A. Elueze, "Geology of Precambrian Schist in Ilesa Area, Southwestern Nigeria," In: P. O. Oluyide, W. C. Mbona, A. E. Ogezi, I. G. Egbuniwe, A. C. Ajibade and A. C. Umeji, Eds., Precambrian Geology of Nigeria, Geological Survey of Nigeria, Nigerian Geological Survey Department, Kaduna, 1988, pp. 77-82.

[20] J. O. Adejuwon and L. K. Jeje, "Land Element of the Environmental System of Ife Area," University of Ife, Ile-Ife, 1975.

[21] R. K. Udoh, "A Comprehensive Geography of West Africa," Heinemann Educational Books (Nigeria) Ltd., Ibadan, 1978, pp. 22-27.
[22] O. T. Odekunle, "Rainfall Characteristics in Ondo Town, Southwest Nigeria," Unpublished M.Sc Thesis, Obafemi Awolowo University, Ile-Ife, 1997.

[23] J. O. Adejuwon, "Agricultural Colonization in the 20th Century in Western Nigeria: Distribution and Vegetation Characteristics," Journal of Tropical Geography, Vol. 39, 1971, pp. 1-10.

[24] O. O. Areola, "Soil and Vegetal Resources," In: J. S. Oguntoyinbo, O. O. Areola and M. Filani, Eds., A Geography of Nigerian Development, 2nd Edition, Heinemann Educational Book (Nig.) Ltd., Ibadan, 1983, pp. 105-126.

[25] G. E. K. Ofomata, "Classification of Soil Erosion with Specific Reference to Anambra State, Nigeria," Environmental Review, Vol. 3, No. 2, 2000, pp. 252-255.

[26] M. Nasri, S. Feiznia, M. Jafari and H. Ahmad, "Using Filed Indices of Rill and Gully in Order to Estimate Erosion and Sediment Analysis. The Case Study of Menderjan Watershed in Isfahan Province, Iran," Proceedings of World Academy of Science, Engineering Technology, Vol. 33, 2008, pp. 225-231.

[27] R. H. Dugdale, "Surveying," George Godwin Ltd., London, 1980.

[28] A. Bannister and S. Raymond, "Surveying," Longman Scientific and Technical, London.

[29] United States Department of Agriculture (USDA), "Handbook on Soil Survey, Field and Laboratory Methods," Report No. 1, 2009.

[30] G. I. Bouyoucos, "Hydrometer Method Improved for Making Particle Size Analysis of Soil," Agronomy Journal, Vol. 54, No. 5, 1962, pp. 464-465. doi:10.2134/agronj1962.00021962005400050028x

[31] M. O. Ibitoye, "Evaluation of Urban Gullies Characteristics in Southwestern Nigeria," Unpublished Ph.D. Thesis. Obafemi Awolowo University, Ile-Ife, 2012, pp. 67-145.

[32] O. Babalola, "Soil Properties Affecting Infiltration, Runoff and Erodibility," In: V. O. Sagua, E. E. Enabor, G. E. K. Ofomata, K. O. Ologe and L. Oyebande, Eds., Ecological Disaster in Nigeria: Soil Erosion, Federal Ministry of Science and Technology, Lagos, 1988, pp. 69-83.

[33] D. Hagan, F. Escobedo, G. Toor, H. Mayer, J. Klein and C. Dobbs, "Soil Bulk Density and Organic Matters in Urban MiamiDade Country, Florida, IFAS," University of Florida, Florida, 2010.

[34] J. H. Gregory, M. D. Dukes, P. H. Jones and L. Miller, "Effect of Urban Soil Compaction on Infiltration Rate," Journal of Soil and Water Conservation, Vol. 6, No. 1, 2006, pp. 117-124.

[35] A. J. T. Guerra, R. Sathler, S. P. Mendes, S. L. S. Silva, T. T. Guerra, I. H. M. Araujo and S. Lima, "Urban Gully Assessment in Sao Louis City (Maranhao State) Brazil, Using Penetrometer Data and Soil Properties," Tropical and Subtropical Geomorphology, Vol. 16, No. 1, pp. 1-10.

[36] P. Pathak, S. P. Wani and R. Sudi, "Gully Control in Semi Arid Tropic (SAT) Watersheds," Journal of International Crop Research Institute for the Semi Arid Tropics (CRISAT), Vol. 2, No. 1, 2005, pp. 22-27. 